\title{
THE INVESTMENT ATTRACTIVENESS OF COMPANIES LISTED ON THE WARSAW STOCK EXCHANGE TO SOVEREIGN WEALTH FUNDS*
}

\author{
Dariusz URBAN \\ (Received: 18 February 2014; revision received: 31 December 2014, \\ accepted: 23 May 2015)
}

The aim of this study is to shed some light on the factors determining the investment decisions of Sovereign Wealth Funds. Using the financial data from companies listed on the Warsaw Stock Exchange, the author employs a logit model to analyse the probability that firms are targeted for investment by the Norwegian Sovereign Wealth Fund. These findings suggest that not only the growth of earnings per share increases the probability of such investment, but that also a company whose shares have been bought by the Government Pension Fund Global has, on average, a higher level of earnings per share than companies not targeted by the Fund. This study contributes to a deeper understanding of the investment activities of the world's largest Sovereign Wealth Fund.

Keywords: Sovereign Wealth Fund, target selection, regression analysis, Warsaw Stock Exchange JEL classification indices: C01, F21, G11

* The author would like to thank Paweł Baranowski, Błażej Socha, and Wojciech Kariozen for their helpful suggestions and constructive comments on the initial drafts of the paper. The author is solely responsible for any errors and omissions.

Dariusz Urban, Assistant Professor at the Faculty of Management, Department of Finance and Strategic Management, University of Lodz, Poland. E-mail: durban@uni.lodz.pl 


\section{INTRODUCTION}

Sovereign Wealth Funds (SWFs) are innovative investment vehicles owned, managed, and controlled by sovereign states, serving to achieve the economic, financial, and social goals of their sponsors. Although they have existed for decades in the shadows, they have become a sign of our times, reversing the way of thinking about government investing and financial relations between developed economies and emerging markets. During the recent financial crisis, SWFs emerged as a new tool of economic policy, as well as an important class of institutional investors. Moreover, these state-run funds are expected to manage an increasing share of foreign exchange reserves in the nearest future, with possible implications for global asset prices and financial imbalances. There are therefore grounds for believing that this group of investors is becoming a solid component in the architecture of global finance.

Despite the fact that in recent years the number of publications in the SWFs field has greatly expanded, the issue of the financial aspects of Sovereign Wealth Funds' behaviour has not been clearly understood. Such areas as investment policy, target selection, asset allocation, and financial performance of investment are still relatively understudied. As Anderloni - Vandone suggest (2012), the literature on SWFs' investments is still scant. Moreover, only a few papers focus on the factors that may attract the interest of SWFs (Ciarlone - Micelli 2014). Given the global investment activity of these state-run funds, the question of which factors determine the selection of companies for investment has become especially relevant to the field of SWFs.

This article will attempt to shed some light on company target selection for investment. This study contributes to a deeper understanding of the investment activity of the largest Sovereign Wealth Fund - the Norwegian Government Pension Fund Global with relevant implications for both market participants and scholars. To the best of our knowledge, this article is the first attempt to use a logit model to analyse the investment attractiveness of companies for the abovementioned SWF.

The structure of the article is as follows: the first section provides the theoretical background of the research, whereas the second section illustrates the methodology employed in the empirical analysis. The third and the fourth sections report and discuss the main findings of the empirical study, and the last one concludes by outlining avenues for future research. 


\section{LITERATURE REVIEW}

Although many definitions of SWFs have been proposed, no universally accepted one exists so far. The key features of these institutional investors are government ownership and control, lack of explicit liabilities, a long-term (intergenerational) investment horizon, exposure to high risk foreign assets, and the management of assets with separation from central banks, with the source of funds coming mainly from oil and gas revenues and foreign exchange reserves (Curzio - Miceli 2010). Sovereign Wealth Funds are a heterogeneous group of institutional investors (Castelli - Scacciavillani 2012), combining in different proportions the characteristics of such entities as central banks, pension funds, mutual funds and hedge funds (Urban 2012). The variety within these state-run funds derives from the different objectives they serve, which often multiply, overlap, and change over time. According to the IMF (2008) taxonomy, there are stabilisation funds, savings funds, reserve investment funds, development funds, and contingent pension reserve funds. An alternative classification has been proposed by Chao (2006) and Dixon - Monk (2010).

The research questions that have fed the recent literature on SWFs can be grouped into four areas (Anderloni - Vandone 2012). The first analyses the objectives of SWF activity, the key features of these investors, their asset allocations and organisational models as well as the size of their investments (Mele 2014; Bertoni - Lugo 2011; Avendano - Santisi 2009). The second includes analyses focusing on the macroeconomic implications of SWFs activity for a single economy as well as for the global financial market (Urban 2011; Sun - Hesse 2009; Beck - Fidora 2008). In the third stream of literature, the focus is on the microeconomic implications of SWFs' investments on targeted firms and, more precisely, on listed companies both in the short and in the long term (Kotter - Lel 2011; Dewenter et al. 2010; Bortolotti et al. 2009). The fourth examines the issue of corporate governance, transparency, and geopolitical concerns (Jiránková 2012; Ćusović 2012; Bassan 2011; Clark - Monk 2009; Gilson - Milhaupt 2008).

In spite of their growing size and that SWFs' assets under management have reached $\$ 6.9$ trillion, a figure larger than that of other institutional investors like hedge funds or private equity funds, academic research on SWFs investment is rather limited. Moreover, the empirical results found in the literature are controversial with reference to the short versus the long term, as well as to investment and divestment issues. Using event study methodology, Bortolotti et al. (2009) analysed SWF acquisitions of equity in publicly traded companies, and documented a significantly positive mean abnormal return around the announcement date. However, in the long term, risk-adjusted abnormal returns of SWFs were 
significantly negative, suggesting that equity acquisitions made by SWFs were followed by a deterioration of firm performance.

Dewenter et al. (2010) have empirically examined the effects of SWFs' investment on the values of the companies in which they invested. The authors found evidence that the announcement of SWFs' stock transactions coincided with significant changes in target firm value. The average announcement date for abnormal stock return was significantly positive for firms whose shares were purchased and significantly negative for companies whose shares were sold. The calculated returns were non-monotonic, first rising, then falling with the share sought for investment, and first falling, then rising in the case of divestments. Analysing the investment strategies, Kotter - Lel (2011) found evidence that SWFs prefer large and poorly performing firms with financial difficulties. They also discovered that SWFs' investments have a positive effect on the target company's stock price around the announcement date, but no substantial effect on firm performance and governance in the long run has been noticed. The empirical finding of their research points to the different impact of transparent $v s$. non-transparent funds. The former have a greater impact on target firm value than the latter. In terms of preferences for target characteristics, the effects on target performance of SWFs are similar to passive institutional investors. Knill et al. (2012) have investigated the relationship between Sovereign Wealth Funds' investment and the return-torisk performance of target firms. They have found evidence that target firms' raw returns declined after the investment. The authors have suggested that SWF investment is associated with a reduction in the compensation of risk over 5 years following acquisition. Employing a multinomial logit framework, they found that SWFs' target firm performance most closely resembles that of other governmentowned firms, suggesting that SWFs may not provide some of the benefits that are offered by other institutional investors. Anderloni - Vandone (2012) have investigated the financial impact of Sovereign Wealth Fund investment in the stock of selected banks during the two time periods of the recent financial crisis. The results of the study suggest that the banks that were targeted by SWFs had a worse financial performance than the other banks. However, considering the whole period, prior to the acute crisis and the period following it, they have not found statistically significant differences between the SWF-backed banks and the non-SWF-backed banks, in terms of return on assets (ROA), return on equity (ROE) or unadjusted and adjusted stock performance.

Focusing on Government Pension Fund Global (GPFG) and the companies listed on the Warsaw Stock Exchange (WSE), Urban (2013) has examined the correlation between the level of financial engagement in the target companies and their financial performance. The results of research show the statistically significant correlation between the level of invested capital and total assets, the value of 
the company, as well as their book value and market capitalisation. The empirical findings also suggest that EBIT, EBITDA, and net profit can have an influence on how much to invest. The issue of credit risk and SWFs investment in targeted companies has been examined by Bertoni - Lugo (2014). Analysing the changes of credit default swap spreads around the investment announcement, these authors found evidence that, on average, the CDS spread of target companies decreases following a SWFs investment. The propensity to invest at the macro level in terms of the characteristics of the target country have been investigated by Ciarlone Micelli (2014). The authors have found that SWFs prefer to invest in countries with a higher degree of economic development, and larger and more liquid financial markets, as well as in countries with institutions that offer a better protection of legal rights and a more stable macroeconomic environment. The empirical findings also suggest that SWFs seem to engage in "contrarian" investment behaviour, i.e. increasing their capital allocation in countries where the crisis hit, which is at variance with the empirical literature on other institutional investors.

Summing up, SWFs' investments have generated considerable research interest; however, to date, the empirical literature has been relatively sparse, mainly due to the difficulties in obtaining comprehensive and systematic data (Heaney et al. 2011) and the information gaps (Ciarlone - Micelli 2014). Since many SWFs do not disclose information about how and in what they invest, the answer to the questions about what determines target selection has therefore remained relatively unanswered. Hence, there is a need for an empirical examination of what financial factors of the firm increase the likelihood of being targeted by SWFs. However, due to the above-mentioned limitations, the scope of such an analysis is driven by availability. Given the fact that according to the LM Transparency Index (SWF Institute 2014), the Norwegian Government Pension Fund Global is a highly transparent SWF, which reports all of its investment, it seems to be reasonable to take the opportunity of undertaking empirical research in this field.

\section{DATA AND RESEARCH METHOD}

Data collected for this research has been obtained from two sources: (i) Emerging Market Information Services, from which all financial indicators for the Polish companies listed on the Warsaw Stock Exchange (WSE) come, and (ii) the web page of GPFG, covering those companies in which the analysed fund has invested. The sample used in this study consisted of 368 companies listed on the WSE, including 47 entities with GPFG as an investor. As many as 70 companies have been excluded due to a lack of data, missing information, or ethical issues. In the latter case, this means that companies engaged in tobacco or alcohol production 
have been excluded as a non-potential target for investment, making the rest of the companies from the sample theoretically equally attractive for the fund from an ethical point of view. The main reason of this was the strong ethical bias and the socially responsible investment behaviour of GPFG (Clark - Monk 2010). This decision on exclusion might to some extent be interpreted as the Ethical Council's restrictions on investment. The final number of companies in the sample was $84 \%$ of all companies listed on the WSE and $94 \%$ of companies with GPFG as an investor at the end of 2012.

In order to discover the factors influencing the target selection for investment, three sets of variables were selected for the initial stage of analysis, and treated as potential variables for targeting companies from the WSE. The first group of financial indicators (profitability indicators) consisted of five variables: return on assets (ROA), return on equity (ROE), return on sales (ROS), return on capital (ROC), and gross profit margin (GPM). The companies' ability to generate profit, measured with relation to the assets, capital, equity being used, or to sales, is a natural measure of the financial effectiveness of the company. Thus, it was assumed that these variables might be the key factors determining propensity to invest. The assumption is also based on previous research which suggests that Sovereign Wealth Funds have a tendency to invest in companies with proven profitability (Fernandes 2009). The second group of financial indicators (size variables) was total operating revenues (TOR), total assets (TA), enterprise value (EV), and market capitalisation (MC). The choice of these variables was done on the basis of the previous research on the investment strategies of SWFs, suggesting that these state-run funds prefer large companies to invest (Kotter - Lel 2011; Boubakri et al. 2011). The third group of variables was price to earning $(\mathrm{P} / \mathrm{E})$, leverage ratio (LR), and earnings per share (EPS). The P/E ratio was used by Bernstein et al. (2013) in examining the differences between domestic and foreign investment of SWFs, while leverage is considered as a potential variable determining investment by Ciarlone - Micelli (2014) and Bertoni - Lugo (2014). However, Bhatt - Sumangala (2012) suggest that earning per share (EPS) is one of a number of variables being used to explain equity value and equity return. Given the fact that the management of wealth and the intergenerational transfer of capital are the main goals of Government Pension Fund Global, it was assumed that the above-mentioned financial indicators may be taken into account before equity investment. The descriptive statistics of the independent variables are included in Table 1.

The attempt to examine the investment propensity of the Norwegian staterun fund in selected Polish companies, or, in other words, the investment attractiveness of Polish companies has been undertaken using microeconometric methodology. The idea was to employ logistic regression (logit model) in which 
Table 1. Descriptive statistics of the independent variables

\begin{tabular}{lccccc}
\hline Variables & Obs. & Mean & Std. Dev. & Min. & Max. \\
\hline$R O A$ & 368 & -0.0215188 & 0.2750558 & -3.1612 & 0.634 \\
$R O E$ & 368 & -0.1015929 & 1.836761 & -30.888 & 8.721 \\
$R O S$ & 368 & -0.2707231 & 2.974739 & -51.7704 & 3.033 \\
$R O C$ & 368 & -0.0690364 & 1.297151 & -19.12 & 9.1831 \\
GPM & 311 & 20.61026 & 27.35877 & -244.49 & 100 \\
TOR & 368 & 1626.315 & 7368.691 & 1 & 120828 \\
$T A$ & 368 & 4040.484 & 16767.97 & 6 & 193480 \\
$E V$ & 368 & 1339.188 & 5305.941 & -246 & 49168 \\
$M C$ & 368 & 1381.576 & 5363.46 & 1 & 46125 \\
$E P S$ & 368 & 0.8858696 & 17.75762 & -258 & 193 \\
$L R$ & 368 & 565.3918 & 5744.672 & -651.14 & 110309.1 \\
$P / E$ & 368 & 12.67793 & 58.78002 & -313.86 & 772 \\
\hline
\end{tabular}

Note: ROA - return on assets, ROE - return on equity, ROS - return on sales, ROC - return on capital, GPM - gross profit margin, TOR - total operating revenues, TA - total assets, EV - enterprise value, MC - market capitalisation, EPS - earnings per share, $\mathrm{P} / \mathrm{E}$ - price to earnings, LR - leverage ratio.

the endogenous variable represents the capital involvement of GPFG, while the exogenous variables are the various financial characteristics of companies. The choice of methodology in this research derived from the binary character of endogenous variables, taking the values 0 for the companies non-targeted for investment, or 1 for the companies targeted for investment. Since logistic function assumes values ranging from 0 to 1 , the results of a logistic regression analysis can therefore be interpreted as a measure of probability of a given event occurring, which is included in the same range.

The logistic function is expressed by the formula:

$$
y=\frac{1}{1+e^{-b_{0}-b_{1} x_{1}-b_{2} x_{2}-\cdots-b_{n} x_{n}}} .
$$

It was taken that the logistic function values of 0.5 and more for a given centre meant that the company should be targeted for investment by the fund, whilst the 
smaller values indicate that statistically the company should not be targeted for investment. Using the above-mentioned indicators as potential variables, several logit models have been estimated. Finally, three of them, models (1), (2) and (3), have been arbitrarily chosen to present as the best models in terms of the significance of parameters, predictive power and pseudo- $\mathrm{R}^{2}$.

The regression equations for the above-mentioned models are expressed by the formulas:

$$
\begin{aligned}
& y=\frac{1}{1+e^{b_{0}-b_{1} T O R-b_{2} E P S},} \\
& y=\frac{1}{1+e^{b_{0}-b_{1} T A-b_{2} E V-b_{3} E P S}}, \\
& y=\frac{1}{1+e^{-b_{0}-b_{1} M C-b_{2} E P S}} .
\end{aligned}
$$

Then, in order to evaluate the predictive accuracy of the logistic regression models, the classification tables were computed. In these tables, the observed values for the dependant outcome and the predicted values were cross-classified. In the next step, due the fact that the coefficients of logistic regressions do not yield direct interpretation, the odds ratios for all the models were computed. The odds ratios give the relative amount by which the odds of the outcomes increase (or decrease) when the value of the independent variable is increased by one unit (is decreased by one unit). In the case of this research, the odds ratios allow the identification of those variables, the changes of which have the strongest influence on the propensity to invest. Finally, to verify the hypothesis about statistically significant differences in terms of financial indicators between the groups of companies with the GPFG as an investor, in comparison to the group of companies without the GPFG as an investor, the marginal effects at the mean were calculated for all three models.

To verify the robustness of the models on the one hand, and to analyse to what extent the portfolio of the GPFG in 2012 can be explained by the previous financial performance of the companies on the other, the models (1), (2) and (3) were tested with the usage of data from 2011, i.e. models (4), (5) and (6), and 2010, i.e. models (7), (8) and (9) presented in Table 2. Additionally, to analyse whether the changes of the variables rather than their absolute level can explain the attractiveness of the companies for investment, the models were tested using incremental data. All the estimations and calculations have been done with the use of STATA. 
Table 2. Logit estimation results for the investment attractiveness of companies: variable GPFG

\begin{tabular}{|c|c|c|c|c|c|c|c|c|c|}
\hline Variables & (1) & (2) & (3) & (4) & (5) & (6) & (7) & (8) & (9) \\
\hline$R O A$ & - & - & - & - & - & - & - & - & - \\
\hline$R O E$ & - & - & - & - & - & - & - & - & - \\
\hline ROS & - & - & - & - & - & - & - & - & - \\
\hline$R O C$ & - & - & - & - & - & - & - & - & - \\
\hline$G P M$ & - & - & - & - & - & - & - & - & - \\
\hline TOR & $\begin{array}{c}0.0000141^{* * *} \\
\quad(0.001)\end{array}$ & - & - & $\begin{array}{c}0.000175^{* * *} \\
(0.000)\end{array}$ & - & - & $\begin{array}{c}0.0002^{* * *} \\
(0.000)\end{array}$ & - & - \\
\hline$T A$ & - & $\begin{array}{c}0.000028^{* *} \\
(0.021)\end{array}$ & - & - & $\begin{array}{c}0.000028^{* *} \\
(0.013)\end{array}$ & - & - & $\begin{array}{c}0.000026^{* *} \\
(0.041)\end{array}$ & - \\
\hline EV & - & $\begin{array}{c}0.000109^{* *} \\
(0.018)\end{array}$ & - & - & $\begin{array}{c}0.0000139^{* *} \\
(0.015)\end{array}$ & - & - & $\begin{array}{c}0.000151^{* * *} \\
(0.010)\end{array}$ & - \\
\hline$M C$ & - & - & $\begin{array}{c}0.000179^{* * *} \\
(0.00)\end{array}$ & - & - & $\begin{array}{c}0.000202^{* * *} * \\
(0.001)\end{array}$ & - & - & $\begin{array}{c}0.000166^{* * *} \\
(0.001)\end{array}$ \\
\hline$E P S$ & $\begin{array}{c}0.119444 * * * \\
\quad(0.001)\end{array}$ & $\begin{array}{l}0.108072^{* * *} \\
\quad(0.003)\end{array}$ & $\begin{array}{l}0.106367 * * * \\
(0.001)\end{array}$ & $\begin{array}{c}0.101332 * * * \\
\quad(0.001)\end{array}$ & $\begin{array}{c}0.096425^{* * *} \\
\quad(0.002)\end{array}$ & $\begin{array}{l}0.088723^{* * *} \\
(0.006)\end{array}$ & $\begin{array}{l}0.172867^{* * *} \\
\quad(0.000)\end{array}$ & $\begin{array}{l}0.164014 * * * \\
\quad(0.001)\end{array}$ & $\begin{array}{c}0.164263^{* * *} \\
\quad(0.001)\end{array}$ \\
\hline$L R$ & - & - & - & - & - & - & - & - & - \\
\hline$P / E$ & - & - & - & - & - & - & - & - & - \\
\hline _cons & -2.48383 & -2.538494 & -2.468102 & -2.496453 & -2.555796 & -2.44593 & -2.582593 & -2.63577 & -2.53577 \\
\hline \multicolumn{10}{|l|}{ Log likehood } \\
\hline & -113.32375 & -109.69942 & -111.3833 & -112.1069 & -107.99447 & -110.46399 & -108.84951 & -105.08071 & -108.29132 \\
\hline Pseudo $\mathrm{R}^{2}$ & $19.18 \%$ & $21.97 \%$ & $20.77 \%$ & $19.22 \%$ & $22.18 \%$ & $20.40 \%$ & $21.64 \%$ & $24.36 \%$ & $22.05 \%$ \\
\hline \multicolumn{10}{|l|}{ Adjusted } \\
\hline Count $\mathrm{R}^{2}$ & $10.60 \%$ & $21.30 \%$ & $17.00 \%$ & $17.00 \%$ & $19.10 \%$ & $19.10 \%$ & $17.00 \%$ & $21.30 \%$ & $17.00 \%$ \\
\hline
\end{tabular}

Notes: This table presents logit estimates of the likelihood of being targeted by a SWF. The dependent variable (GPFG) is the target dummy that equals 1 if a company receives a SWF investment and 0 otherwise. The $t$-statistics where a p-value is reported are in parentheses.

$* * *, * *$ and $*$ indicate significance at the $1 \%, 5 \%$ and $10 \%$ level, respectively.

Description of acronyms: See Table 1. 


\section{EMPIRICAL FINDINGS}

Logit estimations for models (1) to (9) are reported in Table 2. Looking at the results collectively, we see evidence that the likelihood of GPFG investment in the company listed on the WSE is associated with a statistically significant level of total operating revenue, total assets, earnings per share, enterprise value, and market capitalisation of the firm. All models are relatively similar in terms of pseudo R-squared; however, among the models, the highest value of $\mathrm{R}^{2}$ is in model (8): $24.36 \%$. The value of the adjusted count $\mathrm{R}^{2}$ is the highest in models (2) and (8). As regards the EPS, empirical findings suggest that the Norwegian Sovereign Wealth Fund seems more likely to invest in companies characterised by higher degree earnings per share indicators. In all models, the variable EPS is statistically significant at the $1 \%$ level. The statistical significance of other variables (at the $1 \%$ and $5 \%$ level) suggests the size of the company positively affects the likelihood of capital allocation of the Fund. Models (1), (2) and (3) also use data as at 2011 and 2010. The attempt to verify the robustness of the models with the use of incremental data has failed. In all cases, all the variables were not statistically significant, suggesting that the propensity for investment is associated with the absolute level of the financial indicators of the company, rather than with the changes of value.

Among the models explaining the variable GPFG, model (2) seems to be the best for predictions (see Table 3); nevertheless, the predictive power of all the presented models is very similar. In model (2), 14 out of 47 companies have been correctly classified as a target for investment, and 317 out of 322 as a nonpotential target for GPFG. In the case of the first group of targeted companies, the results of classification seem to be relatively weak. Only $29.8 \%$ of the companies with actual capital involvement from the Fund have been classified as a potential target for investment. However, for the second group (non-targeted) as well as for the whole sample, the predictive power of model (2) is relatively high, with $98.8 \%$ and $90 \%$ of companies correctly classified, respectively. Looking at the results of the classifications collectively, we can see the relatively strong predictive power of the models, close to $90 \%$ in all cases; however, within the subsample of targeted companies, the numbers suggest that there might also be other factors that explain the capital involvement of the Norwegian Government Pension Fund Global on the WSE.

Since the coefficients of logistic regressions do not yield direct interpretation, the odds ratios for all models were computed (see Table 4). The highest value of odds ratio in all models was obtained for variable earnings per share. In model (7), every additional 1 PLN earnings per share increases the company's probability of being targeted for investment by $19 \%$. The results of the estimates suggest 
Table 3. Classification table

\begin{tabular}{|c|c|c|c|c|c|c|}
\hline Models & & $\mathrm{Y}=1$ & $\mathrm{Y}=0$ & $\begin{array}{l}\text { Correctly } \\
\text { classified } \\
(\mathrm{Y}=1), \%\end{array}$ & $\begin{array}{l}\text { Correctly } \\
\text { classified } \\
(\mathrm{Y}=0), \%\end{array}$ & $\begin{array}{l}\text { Correctly } \\
\text { classified } \\
\text { Total, } \%\end{array}$ \\
\hline \multirow[b]{2}{*}{ (1) } & $Y=1$ & 10 & 5 & \multirow[b]{2}{*}{21.28} & \multirow[b]{2}{*}{98.44} & \multirow[b]{2}{*}{88.59} \\
\hline & $Y=0$ & 37 & 316 & & & \\
\hline \multirow[b]{2}{*}{ (2) } & $\mathrm{Y}=1$ & 14 & 4 & \multirow[b]{2}{*}{29.79} & \multirow[b]{2}{*}{98.75} & \multirow[b]{2}{*}{89.95} \\
\hline & $\mathrm{Y}=0$ & 33 & 317 & & & \\
\hline \multirow[b]{2}{*}{ (3) } & $\mathrm{Y}=1$ & 12 & 4 & \multirow[b]{2}{*}{25.53} & \multirow[b]{2}{*}{98.75} & \multirow[b]{2}{*}{89.40} \\
\hline & $Y=0$ & 35 & 317 & & & \\
\hline \multirow{2}{*}{ (4) } & $Y=1$ & 11 & 3 & \multirow{2}{*}{23.40} & \multirow{2}{*}{99.03} & \multirow{2}{*}{89.01} \\
\hline & $\mathrm{Y}=0$ & 36 & 305 & & & \\
\hline \multirow[b]{2}{*}{ (5) } & $\mathrm{Y}=1$ & 13 & 4 & \multirow[b]{2}{*}{27.66} & \multirow[b]{2}{*}{98.70} & \multirow[b]{2}{*}{89.30} \\
\hline & $Y=0$ & 34 & 304 & & & \\
\hline \multirow[b]{2}{*}{ (6) } & $\mathrm{Y}=1$ & 12 & 3 & \multirow[b]{2}{*}{25.53} & \multirow[b]{2}{*}{99.03} & \multirow[b]{2}{*}{89.30} \\
\hline & $Y=0$ & 35 & 305 & & & \\
\hline \multirow[b]{2}{*}{ (7) } & $\mathrm{Y}=1$ & 13 & 5 & \multirow[b]{2}{*}{27.66} & \multirow[b]{2}{*}{98.23} & \multirow[b]{2}{*}{89.04} \\
\hline & $Y=0$ & 34 & 304 & & & \\
\hline \multirow[b]{2}{*}{ (8) } & $Y=1$ & 14 & 4 & \multirow[b]{2}{*}{29.79} & \multirow[b]{2}{*}{98.71} & \multirow[b]{2}{*}{89.61} \\
\hline & $Y=0$ & 33 & 305 & & & \\
\hline \multirow[b]{2}{*}{ (9) } & $\mathrm{Y}=1$ & 12 & 4 & \multirow[b]{2}{*}{25.53} & \multirow[b]{2}{*}{98.71} & \multirow[b]{2}{*}{89.04} \\
\hline & $\mathrm{Y}=0$ & 35 & 305 & & & \\
\hline
\end{tabular}

Notes: This table presents the predictive power of logistic regression estimates. The column "Correctly classified $(\mathrm{Y}=1)$ " illustrates the percentage of companies with GFPF as an investor, being classified by models as a potential target for investment. The column "Correctly classified $(\mathrm{Y}=0)$ ") illustrates the percentage of companies without GPFG as an investor, being classified by models as a non-potential target for investment. The column "Correctly classified total" illustrates the percentage of all companies from the sample being correctly classified as both a potential target and a non-potential target for investment. The column "Y=1" illustrates the number of companies with GPFG as an investor divided into subgroups of correctly classified and non-correctly classified. Similarly, the column "Y=0" illustrates the number of companies without GPFG as an investor divided into subgroups of correctly classified and non-correctly classified. 


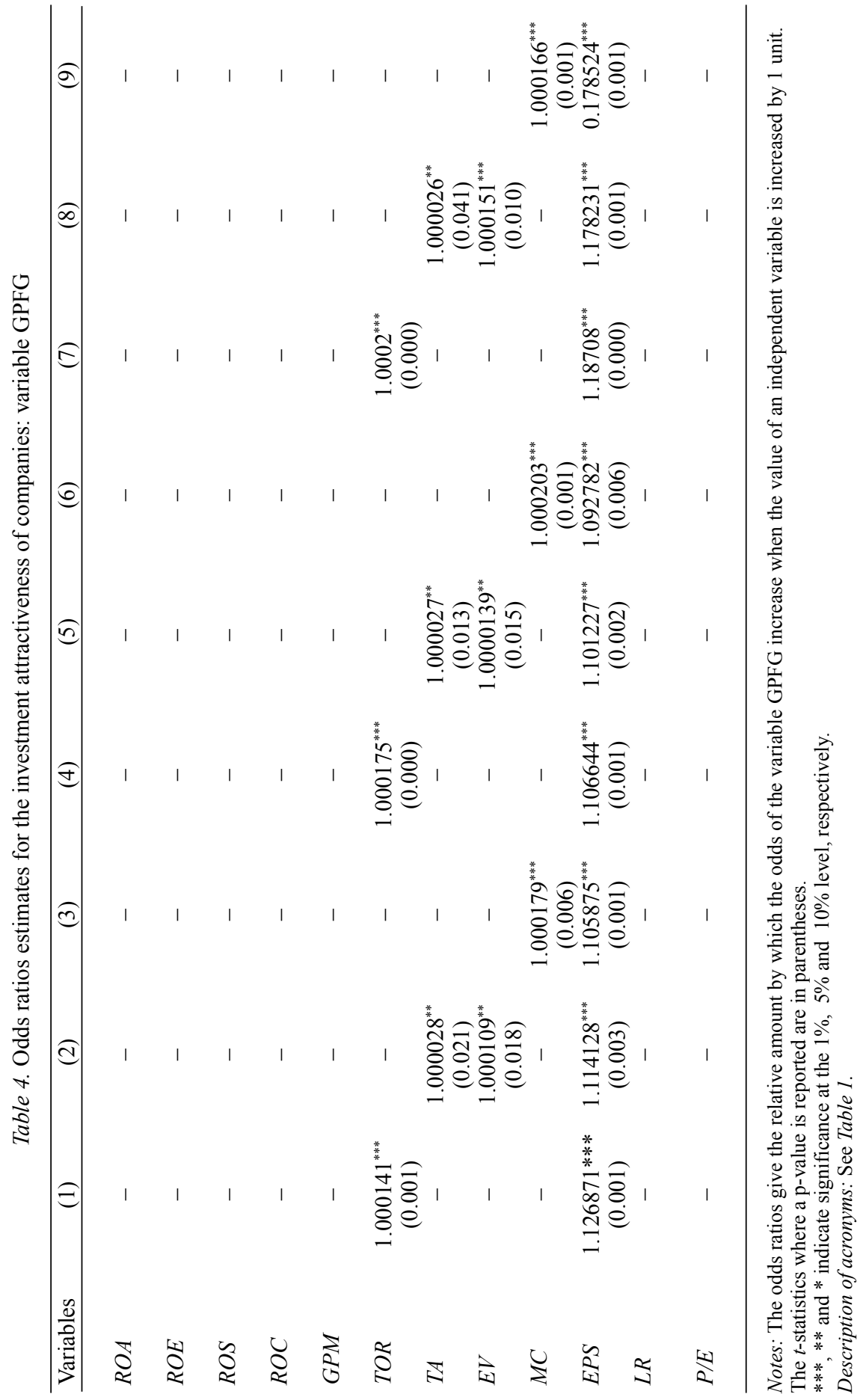


INVESTMENT PREFERENCES OF SOVEREIGN WEALTH FUNDS

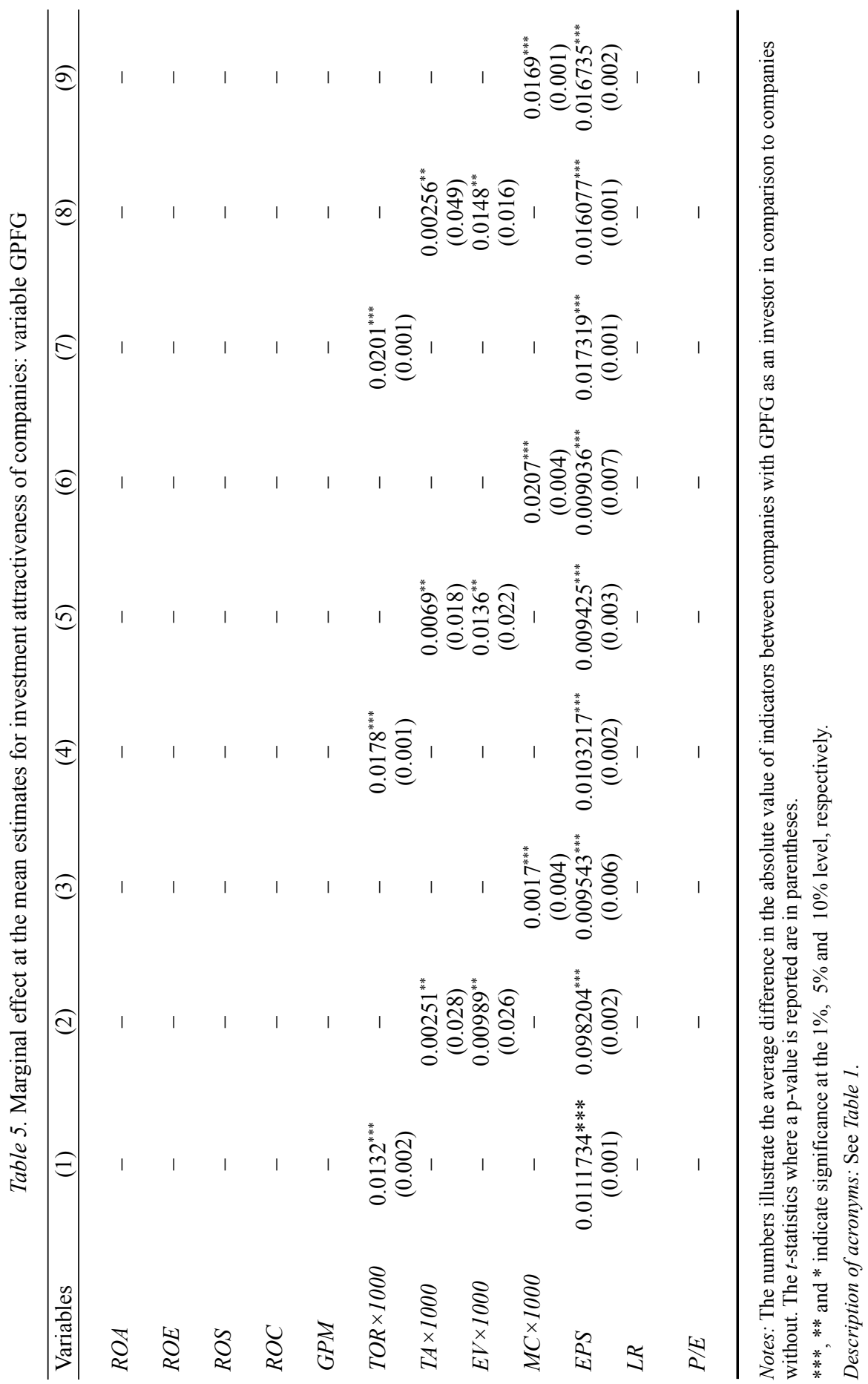


that the relative amount by which the odds of the variable GPFG increase is the highest in the case of the EPS changes in 2010, suggesting that the increase of EPS in the potential target companies determine the propensity to invest the most. The changes of the other variables, although in all cases statistically significant, seem not to influence the propensity to invest.

As regards the marginal effects at the mean (Table 5), the empirical results suggest that, on average, a company with GPFG as an investor, in comparison to a company without GPFG as an investor, has a higher level of earnings per share (by 0.098204 in model (2), by 0.017319 in model (7), and lastly by 0.016735 in model (9)). It is worth emphasising that in each of the models, the variable EPS is statistically significant at the $1 \%$ level. For the rest of the variables in all models, the difference between the subsamples seems not to be significant, although the p-value is reported at the $1 \%$ and $5 \%$ level. The results of the marginal effects at the means estimates confirm the previous findings concerning factors determining propensity to invest, based on logistic regression estimates and odds ratios calculations.

\section{DISCUSSION}

The findings of this study offer important implications for both research and practice.

(1) This study contributes to the growing body of literature on Sovereign Wealth Funds by applying logistic regression to analyse propensity to investment. The use of the empirical tool mentioned above not only allows for the calculation of the company's likelihood of being targeted for investment by SWFs and other types of investors as well, but also to predict the future equity portfolio of investors. The possibility of using this empirical tool was already confirmed in the article by Ciarlone - Micelli (2014).

(2) As regards empirical findings, in all the presented models, the variable EPS with significance at the $1 \%$ level has a positive influence on GPFG decision whether or not to invest in the company. The results suggest that the increase of earnings per share by 1 PLN increases the company's probability of being targeted for investment by $19 \%$ in model (7), and by $18 \%$ in models (8) and (9). In the case of other models, the number ranges from $9 \%$ to $13 \%$. The results are consistent with the author's previous research (Urban 2013), in which by analysing the level of capital invested by GPFG in companies from the WSE, he found a relatively weak but statistically significant correlation between the level of invested capital and the variable earnings per share. The other variables used in logistic regression estimations, although statistically significant, seem to have 
very little or no impact on the decision of which company to invest in. However, the fact that in all the models' variables, the total operating revenues, total assets, enterprise value, and market capitalisation were statistically significant might be, to some extent, interpreted as similar to the results obtained by Heaney et al. (2011) and those of Kotter - Lel (2011), suggesting that SWFs prefer investing in large companies.

(3) The contribution of this study lies in its potential to stimulate further research in this field. The relatively low level of predictive power of the presented logit models in the case of the targeted companies suggests the possibility of other factors that determine investments. The question also arises of whether the findings generalise the other state-run funds, the other countries from the region, or different emerging markets all around the world. Future studies should attempt to answer this question.

(4) This study also has practical implications. For companies listed on the WSE as well as for the other companies from the region that are searching for a Sovereign Wealth Fund as an active and long-term investor, this research points out that maximising earnings per share increases the probability of targeting the company for investment.

We have to acknowledge several important limitations to our study. (1) There are grounds to believe that GPFG as a responsible investor also considers nonfinancial factors before investing, for example, corporate governance or broadly environmantal, social and governance (ESG) factors. Hence, future research should include these variables. Such data was unobtainable for Polish companies in 2012. Broadening the scope of the analysis presented in the article by including non-financial factors would be an interesting avenue for future research. (2) The empirical part of this article does not take into account the global investment policy of GPFG, which might influence company selection on different regional markets. (3) As it was pointed out by Rose (2013), SWFs are a heterogeneous group of investors with different objectives, hence the empirical findings of this research cannot be simply applied to other state-run funds. Despite the above limitations, however, this study addresses the paucity of substantive empirical studies on the financial aspects of SWFs' activity.

\section{CONCLUSIONS}

With $\$ 6.9$ trillion assets under management, SWFs prove to be an important class of institutional investors in global financial markets, with possible implications for asset prices and international financial imbalances. There are grounds to believe that this group of investors is becoming a solid component in the architec- 
ture of global finance, with contribution to growth and stability on regional and national markets by providing long-term capital. For these reasons, it is important to understand the factors driving their asset allocation choices, also on the equity markets in the emerging economies of the EU.

The motivation of this study was to shed some light on the literature of SWFs about the factors determining the investments decisions of these state-run funds. To the best of our knowledge, this research was the first attempt to examine the relationship between the financial performance of target companies from the WSE and the investment behaviour of the largest SWF, the Norwegian Government Pension Fund Global. By employing a logit model, this study examines the company's likelihood of being targeted by GPFG. The empirical findings of econometric analysis suggest that the growth of earnings per share increase the probability of investment, and also that the company with GPFG as an investor has on average a higher level of earnings per share in comparison to the company non-targeted by GPFG. The results seem to confirm the usefulness of the proposed research method, which can also be adopted for analysing groups of investors other than SWFs. However, the predictive power of the models presented in this paper shows the need for further research on factors influencing the propensity to invest on the equity market. The results of this research have also practical implications for companies listed on the WSE and other markets in the region, as well as for companies searching for Sovereign Wealth Funds as active and long-term investors.

\section{REFERENCES}

Anderloni, L. - Vandone, D. (2012): Sovereign Wealth Fund Investments in the Banking Industry. Universita degli Studi di Milano, Working Paper, 24.

Avendano, R. - Santisi, J. (2009): Are Sovereign Wealth Funds' Investments Politically Biased? A Comparison with Mutual Funds. OECD Development Centre, Working Paper, 283.

Bassan, F. - (2011): The Law of Sovereign Wealth Funds. Cheltenham, UK - Northmapton, MA, USA: Edward Elgar.

Beck, R. - Fidora, M. (2008): The Impact of Sovereign Wealth Funds on Global Financial Markets. European Central Bank, Occasional Paper Series, 91.

Bernstein, S. - Lerner, J. - Schoar, A. (2013): The Investment Strategies of Sovereign Wealth Funds. The Journal of Economic Perspectives, 27(2): 219-238.

Bertoni, F. - Lugo, S. (2011): Testing the Strategic Asset Allocation of Stabilization Sovereign Wealth Funds. Social Science Research Network, 1944508.

Bertoni, F. - Lugo, S. (2014): The Effect of Sovereign Wealth Funds on the Credit Risk of Their Portfolio Companies. Journal of Corporate Finance, 27(1): 21-35.

Bhatt, P. - Sumangala, J. K. (2012): Impact of Earnings per Share on Market Value of an Equity Share: An Empirical Study in Indian Capital Market. Journal of Finance, Accounting and Management, 3(2): 1-14. 
Bortolotti, B. - Fotak, V. - Megginson, W. - Miracky, W. (2009): Sovereign Wealth Funds Investment Patterns and Performance. Fondazione Eni Enrico Matte Working Paper, 22.

Boubakri, N. - Cosset, J. C. - Samir, N. (2011): Sovereign Wealth Fund Acquisitions: A Comparative Analysis with Mutual Funds. International Finance Review, 12(V): 355-389.

Castelli, M. - Scacciavillani, F. (2012): The New Economics of Sovereign Wealth Funds. Chichester: Wiley Finance.

Chao, C. (2006): The Rise of Global Sovereign Wealth Funds. Modern Bankers, 10.

Ciarlone, A. - Micelli, V. (2014): Are Sovereign Wealth Funds Contrarian Investors? Banca D'Italia, Working Papers, 972.

Ciżkowicz, P. - Rzońca, A. (2015): Inflation Targeting and Its Discontents: The Case of Poland. Acta Oeconomica, 65(S1): 109-124.

Clark, G. L. - Monk, A. H. B. (2009): The Oxford Survey of Sovereign Wealth Funds' Asset Managers. Social Science Research Network, 1432078.

Clark, G. L. - Monk, A. H. B. (2010): The Norwegian Government Pension Fund: Ethics over Efficiency. Rotman International Journal of Pension Management, 3(1):14-19.

Curzio, A. Q. - Miceli, V. (2010): Sovereign Wealth Funds. A Complete Guide to State-Owned Investment Funds. Petersfield: Harriman Finance Essentials.

Ćusović, S. (2012): Sovereign Wealth Funds in the Globalization of Financial Markets. Perspectives of Innovations, Economics and Business, 10(1): 5-13.

Dewenter, K. L. - Han, X. - Malatesta, P. H. (2010): Firm Values and Sovereign Wealth Funds Investments. Journal of Financial Economics, 98(2): 256-278.

Dixon, A. - Monk, A. (2010): Rethinking the Sovereign in Sovereign Wealth Funds. Social Science Research Network, 1652701.

Fernandes, N. (2009): Sovereign Wealth Funds - Investment Choices and Implications around the World. Social Science Research Network, 1341692.

Gilson, R. J. - Milhaupt, C. J. (2008): Sovereign Wealth Funds and Corporate Governance: A Minimalist Responds to the New Mercantilism. Stanford Law Review, 60(5): 1345-1370.

Gruszczyński, M. (2012): Mikroekonometria. Modele i metody analizy danych indywidualnych (Models and Methods of Individual Data Analysis). Warszawa: Oficyna Wolters Kluwer Business, Microeconometrics.

Heaney, R. - Li, L. - Valencia, V. (2011): Sovereign Wealth Fund Investment Decisions: Temasek Holdings. Australian Journal of Management, 36(1): 109-120.

IMF (2008): Sovereign Wealth Funds - A Work Agenda. Washington, D.C.

Jiránková, M. (2012): Nation-States as Investors in a Globalized World. Ekonomický časopis, 60(8): 854-870.

Knill, A. M. - Lee, B. S. - Mauck, N. (2012): Sovereign Wealth Fund Investment and the Return-toRisk Performance of Target Firms. Journal of Financial Intermediation, 21(2): 315-340.

Kotter, J. - Lel, U. (2011): Friends or Foes? Target Selection Decisions of Sovereign Wealth Funds and Their Consequences. Journal of Financial Economics, 101(2): 360-381.

Mele, M. (2014): On Asset Allocation Studies for Sovereign Wealth Funds. International Journal of Financial Economics, 2(4): 169-180.

Rose, P. (2013): Sovereign Investing and Corporate Governance: Evidence and Policy. Public Law and Legal Theory Working Paper Series, 192.

Sun, T. - Hesse, H. (2009): Sovereign Wealth Funds and Financial Stability - An Event Study Analysis. IMF Working Paper, 239.

SWF Institute (2014): http://www.swfinstitute.org/fund-rankings/ 
Urban, D. (2011): The Role of Sovereign Wealth Funds in Global Management of Excess Foreign Exchange Reserves. Lodz University, Comparative Economic Research: Central and Eastern Europe, 14(2): 143-158.

Urban, D. (2012): Państwowe fundusze majątkowe jako inwestor finansowy. Zarządzanie finansami firm - teoria i praktyka (Sovereign Wealth Funds as a Financial Investor - Theory and Practice). Prace Naukowe Uniwersytetu Ekonomicznego we Wrocławiu, 271: 434-442. Research Papers of Wroctaw University of Economics.

Urban, D. (2013): Czy wartość to przesłanka do inwestowania? Jako udziałowiec w spółce portfelowej (Value as a Premise for Investing? Government Pension Fund as Shareholder in a Portfolio Company). Zarzadzanie i Finanse, 14(4): 199-209. 